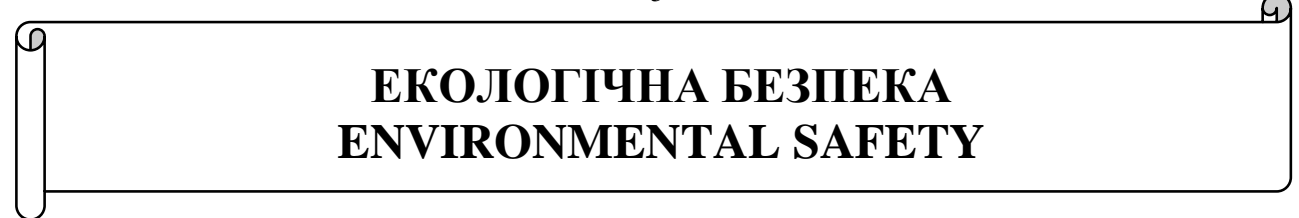

UDK 631.4:(550.42:546.95):628.542](477)

Oleksandr T. Azimov ${ }^{1}$, D. S. (Geology), Leading Researcher ORCID ID 0000-0002-5210-3920e-mail:azimov@casre.kiev.ua

Oleksandr M. Trofymchuk ${ }^{2}$, D. S. (Engineering), Professor, Corresponding Member of NASU, Director

ORCID ID 0000-0003-3782-4209 e-mail: itelua@kv.ukrtel.net

Iryna V. Kuraeva ${ }^{3}$, D. S. (Geology), Professor, Head of Department ORCID ID 0000-0003-3113-7782 e-mail:ki4412674@gmail.com

Sergii P. Karmazinenko ${ }^{4}, \mathrm{PhD}$, Senior Scientist

ORCID ID 0000-0001-8268-7851 e-mail: karmazinenko78@gmail.com

${ }^{1}$ Scientific Centre for Aerospace Research of the Earth of IGS of NASU, Kyiv, Ukraine ${ }^{2}$ Institute of Telecommunications and Global Information Space of NASU, Kyiv, Ukraine ${ }^{3}$ M.P. Semenenko Institute of Geochemistry, Mineralogy and Ore Formation of NASU, Kyiv, Ukraine

${ }^{4}$ Institute of Geography of NASU, Kyiv, Ukraine

\title{
ESTIMATIONS OF HEAVY METALS IN SOILS AND DIFFERENT LANDSCAPE COMPONENTS WITHIN THE MUNICIPAL SOLID WASTE DISPOSAL AREAS
}

\begin{abstract}
The comprehensive geoecological study of the area closed to the northwestern part of Landfill No 5 for the municipal solid waste disposal shows the ecologically negative impact on the environment. It is determined that the existing soils are affected by the significant geochemical transformation. They are characterized by the considerable accumulations of the heavy metals (HMs). In comparison with the conventional pure soils the soil contents of $\mathrm{Cu}, \mathrm{Zn}, \mathrm{Ni}, \mathrm{Cr}$ and $\mathrm{Pb}$ are 8, 12, 3, 2, 17 times more, respectively.

The anomalous high HMs pollution for the bottom deposits is identified: for $\mathrm{Zn}-$ in $800 \mathrm{mg} / \mathrm{kg}$ that is 14 times more than maximum allowable concentrations (MAC); for $\mathrm{Cu}-150 \mathrm{mg} / \mathrm{kg}$ that is 4.5 times more than MAC. Average Pb content there exceeds its MAC and is equal to $72 \mathrm{mg} / \mathrm{kg}$. Therefore, the bottom deposits have the hazardous level of pollution.

It is shown that the elements of considerable accumulations in grass vegetation are $\mathrm{Cu}, \mathrm{Cr}$ and $\mathrm{Ni}$ at the biological absorption coefficient more 2.0.

The physical and chemical studies of surface waters show that the contents of microelements ( $\mathrm{F}, \mathrm{Cr}, \mathrm{Ni}, \mathrm{Cu}, \mathrm{Fe}_{\text {tot. }}$ and $\mathrm{Pb}$ ) there don't exceed the $\mathrm{MAC}$, but they are higher than the background values.
\end{abstract}

(C) O.T. Azimov, O.M. Trofymchuk, I.V. Kuraeva, S.P. Karmazinenko, 2019 
The comparison of the average chemical composition for the ground water samples from the wells of the Landfill area and the regulatory standards indicates that the standard general sanitary criteria for pollution level of these waters belong to the middle and high levels with the considerable exceeds of the MACs for Fe and Ni.

Keywords: Landfill; solid waste; heavy metals; landscape; soil; geochemical analysis

\title{
О.Т. Азімов ${ }^{1}$, О.М. Трофимчук ${ }^{2}$, І.В. Кураєва ${ }^{3}$, С.П. Кармазиненко ${ }^{4}$
}

${ }^{1}$ Науковий центр аерокосмічних досліджень Землі ІГН НАН України, м. Київ, Україна ${ }^{2}$ Інститут телекомунікацій і глобального інформаційного простору НАН України, м. Київ, Україна

${ }^{3}$ Інститут геохімії, мінералогії та рудоутворення імені М.П. Семененка НАН України, м. Київ, Україна

${ }^{4}$ Інститут географії НАН України, м. Київ, Україна

\section{ОЦНКА ВМІСТУ ВАЖКИХ МЕТАЛІВ У ГРУНТАХ ТА ІНШИХ КОМПОНЕНТАХ ЛАНДШАФТУ В РАЙОНАХ ЗАХОРОНЕННЯ ТВЕРДИХ ПОБУТОВИХ ВІДХОДІВ}

\begin{abstract}
Анотація. Комплексними геоекологічними дослідженнями району, прилеглого до північно-західної частини полігону № 5 з поховання твердих побутових відходів, встановлено екологічно негативний його вплив на довкілля. Виявлено, що наявні трунти зазнали значної геохімічної трансформації. Вони характеризуються значним накопиченням важких металів (ВМ). Порівняно з умовно чистими трунтами вміст Си в них у 8 разів більше, $\mathrm{Zn}-\mathrm{y} 12, \mathrm{Ni}-\mathrm{y} 3$, $\mathrm{Cr}-$ у 2, $\mathrm{Pb}-$ в 17 разів.

Встановлено аномально високе забруднення донних відкладів ВМ: иинком - до 800 мг/кг (у 14 разів більше гранично допустимих концентрацій - ГДК), міддю - до 150 мг/кг (у 4,5 рази вище ГДК). Середній вміст свинщую в них перевищує ГДК $i$ становить 72 мг/кг. Отже, донні відклади характеризуються небезпечним рівнем забруднення.

Виявлено, що до елементів значного накопичення у трав 'янистій рослинності належать $\mathrm{Cu}, \mathrm{Cr}, \mathrm{Ni}$ з коефіцієнтами біологічного поглинання понад 2,0.

За результатами фізико-хімічних досліджень поверхневих вод визначено, що вміст в них мікроелементів ( $\left.\mathrm{F}, \mathrm{Cr}, \mathrm{Ni}, \mathrm{Cu}, \mathrm{Fe}_{3 а г, ~} \mathrm{~Pb}\right)$ не перевищує ГДК, однак, він вище фонових значень.

Порівняння середнього хімічного складу проб трунтових вод зі свердловин району полігону з нормативними показниками свідчить, щзо загальносанітарні показники ступеня забруднення перших з них належать до категорї середнього і високого ступеня забруднення зі значним перевищенням ГДК по Fe i $\mathrm{Ni}$.
\end{abstract}

Ключові слова: полігон; побутові відходи; важкі метали; ландшафт; трунт; геохімічний аналіз

\section{Актуальність дослідження}

Вивчення еколого-геохімічного стану об'єктів довкілля територій, що перебувають під впливом різноманітних викидів, пов'язаних 3 твердими побутовими відходами (ТПВ), у даний час є дуже актуальним. В Україні налічується близько 6 тис. сміттєзвалищ і полігонів загальною площею понад 9 тис. га, конструкції більшості з яких не відповідають санітарно-гігієнічним нормам. Наслідки впливу полігонів ТПВ на навколишнє середовище і на здоров'я населення, що живе поблизу цих територій, викликають серйозні побоювання [1-8 та ін.]. 
Найбільшого забруднення зазнають підземні та поверхневі води, грунти i поверхневі відклади, рослинність. Комплексні дослідження природних утворень, прилеглих до таких полігонів, необхідні для їх об'єктивної екологогеохімічної оцінки. Геохімічні процеси, які відбуваються на таких територіях, призводять до значної трансформації екологічного стану поверхневих відкладів, природних вод, біогеохімічних показників тощо.

Мета нашого дослідження - визначення основних геохімічних показників біокосних систем району захоронення ТПВ на прикладі Київського полігону № 5. Він введений в експлуатацію у 1986 році. 3 усіх відходів м. Києва (1,2 млн т на рік) на ньому захоронюється понад 400 тис. т. Наразі на полігоні № 5 захоронено близько 7 млн т ТПВ. За приблизно 33 роки експлуатації потужностей полігону вже недостатньо, в його тілі під дією опадів накопичився фільтрат. 32006 р. йде мова про повне закриття полігону № 5 через його критичний екологічний стан, насамперед пов'язаний з витіканням фільтрату в землю та забруднення ним довкілля, передусім підземних вод.

\section{Характеристика об'єкта дослідження}

Полігон № 5 розміщений приблизно в 11 км на південь від житловопромислової забудови південної частини м. Києва та в 4,5 км на північний захід від с. Великі Дмитровичі Обухівського району Київської області, безпосередньо поблизу західної околиці с. Підгірці, в одному кілометрі від неї. У 500 м західніше полігону вже простежується контур с. Креничі. ТПВ складуються в межах центральної частини вододільної поверхні, яка 3 півночі обмежена Ходосівською балкою урочища «Марусин Яр» (рис. 1). Полігон складається 3 двох майданчиків (або черг, карт) складування - «А» та «Б», на яких під ТПВ відведено площу 35,75 га. Загальна площа полігону становить 63,7 га.

Стосовно геологічної будови Київський полігон № 5 локалізований в межах розвитку неогенових $(\mathrm{N})$ та четвертинних (Q) утворень. Сучасний грунт складений алювіальними різновидами, гумусованими суглинками та супісками. Товщина їх складає $0,3-1,0$ м.

За ландиафтно-геохімічним районуванням територія полігону № 5 розташована в зоні зі здатністю до самоочищення та акумуляції [9]. Розвинені ці ландшафти на лесах і кристалічних породах. В їх межах добре виявляється низхідна і висхідна міграція хімічних елементів, а також площовий змив важких металів (BM) з грунтовим шаром і розвантаженням грунтових вод у зниженій частині рельєфу (долини річок, днища ярів). Ці процеси сприяють очищенню ландшафтів від техногенного забруднення. Разом з тим, ландшафти цього класу зазнають значних еколого-геохімічних навантажень внаслідок забруднення ВМ і токсичними речовинами, що надходять у довкілля з відходами.

\section{Методика дослідження}

Продовжуючи розпочаті раніше роботи, які стосувалися північно-східної частини полігону [5-8], у листопаді 2018 року виконано польові рекогносцирувальні комплексні дослідження північно-західної його частини і прилеглих до неї площ з наступним лабораторно-камеральним аналізом отриманих матеріалів (рис. 1-3). Вони включали такі види робіт: 
- візуальний аналіз гідролого-геоморфологічних особливостей території досліджень;

- відбір проб з різних компонентів ландшафту в межах 6 площадок спостережень і подальший їх геохімічний аналіз:

- грунту 3 інтервалу глибин 0-5 cм (у межах усіх 6 площадок спостережень);

- поверхневої води (у межах площадок спостережень №o 1, 5, 6);

- донних відкладів (у межах площадок спостережень №o 5 і 6);

- рослинності (у межах площадок спостережень №№ 3, 4, 5, 6).

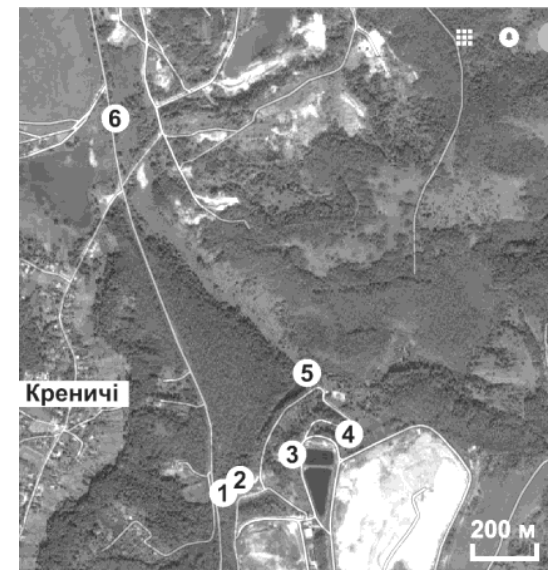

Рис. 1 - Картосхема розташування площадок спостережень вздовж рекогносцирувального поперечнопоздовжнього профілю в зоні впливу північно-західної частини полігону

№ 5. Як підложка використано космічний знімок, отриманий 3 Інтернет-джерела [10].

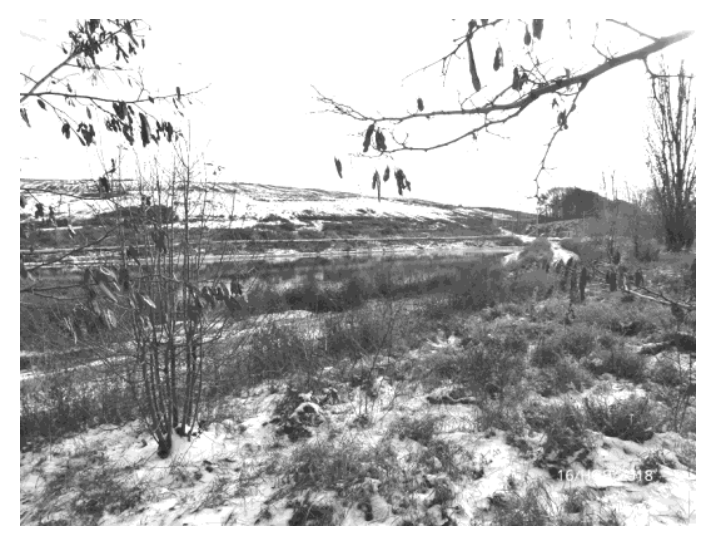

Рис. 2 - Фотографічне зображення північно-західного схилу черги «А» полігону № 5 і прилеглого основного ставкафільтратонакопичувача, виконане з району площадки спостережень № 3

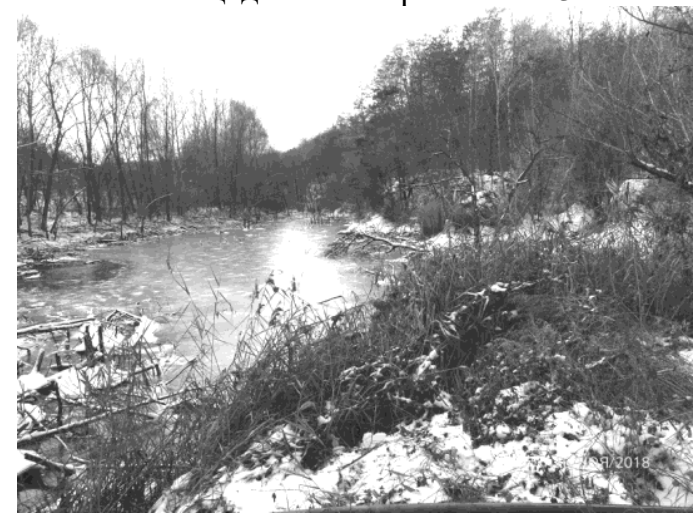

Рис. 3 - Фотографічне зображення штучного ставка у нижній частині балки, що облямовує полігон № 5 із заходу і північного заходу (район площадки спостережень № 5)

Крім цього, виконано фотографування місць відбору проб і прилеглих до них районів (зроблено 65 фотографій), що характеризують відповідну ландшафтну обстановку (деякі з них представлені на рис. 2, 3).

Спостереження 3 відбором зазначених проб у натурних умовах виконані уздовж поперечно-поздовжнього профілю на п'яти основних площадках, що 
приурочені до відмінних ландшафтно-геологічних умов (рис. 1). Профіль розпочинався у днищі балки біля їі західного, крутого схилу (з кутами падіння близько $45-50^{\circ}$ ), уздовж якого спостерігався тимчасовий потічок у рівчаку 3 напрямком течії на північ (площадка спостережень № 1). Ця балка з заходу і північного заходу обмежує розлогу вододільну поверхню, на якій розміщені черга «Б» полігону № 5 та його основний ставок-фільтратонакопичувач. На східному боці потічка була закладена площадка спостережень № 2. За результатами візуальних досліджень геолого-геоморфологічні умови площадок спостережень №№ 1 і 2 однакові.

Далі профіль наземних досліджень продовжувався у північно-східному напрямку поперек балки та іiі східного крутого схилу. Останній поступово переходив у західний, дуже крутий біля свого верхів'я схил вододільного плато (кути падіння схилу біля верхів’я становили до 50-60). Саме в межах цього плато розташована черга «А» та основний ставок-фільтратонакопичувач полігону № 5 (рис. 1, 2). На плато в районі північно-західного контуру ставка закладено площадку спостережень № 3. Площадку спостережень № 4 закладено в межах північно-західного схилу вододілу, неподалік відповідного контуру черги «А» полігону.

Потім профіль різко змінив своє простягання з північно-східного на північнозахідне, і в районі дамби, що перегороджує заповнену водоймою балку (в іiі днищі гіпсометрично вище розташовані площадки спостережень №№ 1 і 2), було закладено площадку спостережень № 5 (рис. 1, 3). Закінчувався профіль площадкою спостережень № 6 в 1 км від північно-західного контуру полігону, тобто фактично вже в межах фону (рис. 1).

Як і в попередніх дослідженнях [5-8], у роботі застосовано комплекс методів. Більш повна характеристика комплексу наведена у публікаціях [5, 7]. Зокрема, опробування трунту 3 інтервалу глибин 0-5 см здійснювалося за методикою конверта відповідно до вимог ГОСТ 17.4.4.02-84 [11].

Проби поверхневої води об'ємом 1,5 л кожна відібрані відповідно до вимог ГОСТ Р 51592-2000 [12]. 3 однієї з водойм полігону № 5 та $з$ однієї з району його вПливу взято, згідно з ГОСТ 17.1.5.01-80 [13], проби донних відкладів.

Опробування представницьких видів рослинності на території досліджень проведено паралельно з відбором грунтових проб. На площадці спостережень № 3 рослинність представлена осокою (Carex), на №№ 4 і 6 - різнотрав’ям, на № 5 - пирієм повзучим (Agropyrum repens). На площадці спостережень № 6 було взято пробу опалого листя осики (Populus tremula).

Для визначення вмісту ВМ у грунтах, рослинності, донних відкладах використано фізико-хімічні (атомно-абсорбційний, спектральний) та хімічний (силікатний аналіз) методи дослідження. Вивчення форм знаходження ВМ у грунтах виконано методом послідовних витяжок за методикою А.I. Самчука [14].

Коефіцієнти біологічного поглинання (КБП) елементів розраховано за формулою І.А. Авессаломової [15].

\section{Викладення основного матеріалу та обговорення}

Особливе значення при комплексному вивченні територій розміщення ТПВ мають ґрунтові відклади. Слід відмітити, що об'єктивним показником техногенно забруднених грунтів $є$ вміст у них рухомих форм полютантів. 
Грунти на територіях, що не зазнають техногенного забруднення (фонові), належать до високородючих 3 позитивними фізико-хімічними характеристиками [16].

За результатами проведених нами аналітичних досліджень встановлено, що грунтові відклади, які перебувають під впливом північно-західної частини полігону № 5, зазнали значної геохімічної трансформації, як і ті, на які впливає діяльність північно-східної його частини [5-8]. Зокрема, однією з основних характеристик техногенних грунтів $є$ їхня буферність. Вона відображає здатність грунтів протистояти антропогенному забрудненню. Для оцінки цієї ознаки грунтів використовується коефіцієнт буферності $\left(\mathrm{K}_{\sigma}\right)$ [14]. Коефіцієнти буферності досліджених грунтів у районі полігону ТПВ та їхні фізико-хімічні властивості, а також порівняння їх 3 аналогічними показниками для фонових грунтів представлені в таблиці 1.

Таблиця 1 - Фізико-хімічні властивості фонових і техногенно забруднених грунтів у районі полігону № 5

\begin{tabular}{|l|c|c|c|c|c|}
\hline \multicolumn{1}{|c|}{ Грунти } & $\begin{array}{c}\text { Поглинені } \\
\text { катіони, } \\
\text { мг-екв. на 100 г }\end{array}$ & $\begin{array}{c}\mathrm{C}_{\text {орг., }} \\
\%\end{array}$ & $\begin{array}{c}\mathrm{pH} \\
\text { (водн.) }\end{array}$ & $\mathrm{K}_{\sigma}$ & $\begin{array}{c}\text { Вміст ВM, } \\
\text { мг/кг }\end{array}$ \\
\hline $\begin{array}{l}\text { Темно-сірі опідзолені } \\
\text { на лесах (фонові) }\end{array}$ & 32,82 & 8,21 & 7,2 & 20,1 & $\begin{array}{c}\mathrm{Cu} 22 \\
\mathrm{Zn} 20 \\
\mathrm{Ni} 15 \\
\mathrm{Cr} 50 \\
\mathrm{~Pb} 12\end{array}$ \\
\hline $\begin{array}{l}\text { Техногенно } \\
\text { забруднені }\end{array}$ & 14,26 & 2,5 & 6,5 & 4,2 & $\begin{array}{c}\mathrm{Cu} 180 \\
\mathrm{Zn} 250 \\
\mathrm{Ni} 42 \\
\mathrm{Cr} 100 \\
\mathrm{~Pb} \mathrm{200}\end{array}$ \\
\hline
\end{tabular}

Отже, наведені дані черговий раз підтверджують факти, що в техногенно забруднених грунтах відбувається зменшення вмісту поглинених катіонів і вмісту $\mathrm{C}_{\text {орг. }}$ Також у них значно зменшується $\mathrm{K}_{\sigma}$.

Одним 3 найбільш важливих показників грунтів є накопичення в них ВМ. Порівняно 3 умовно чистими (фоновими) грунтами [16] вміст $\mathrm{Cu}$ у досліджених грунтах району полігону № 5 у 8 разів більше, $\mathrm{Zn}-$ у 12 разів, $\mathrm{Ni}-$ у $3, \mathrm{Cr}-$ у $2, \mathrm{~Pb}-$ в 17 разів.

Як ми бачимо, вплив полігону ТПВ призвів до порушення природного співвідношення форм знаходження ВМ у грунтах. У фонових грунтах домінують міцнозв'язані форми (60-90\% від загального вмісту). Унаслідок забруднення ВМ у грунтах збільшується кількість рухомих форм (водорозчинна та іонообмінна): $\mathrm{Zn}$ - в 4 рази, $\mathrm{Ni}-$ у 5 разів, $\mathrm{Cu}-$ у 6 разів, $\mathrm{Pb}$ - у 8 разів. Це відбувається внаслідок надходження у грунти ВМ у вигляді оксидів та інших сполук, їх підвищена міграційна здатність пояснюється істотним зниженням коефіцієнта буферності грунтів та зменшенням ємності грунтово-поглинального комплексу.

За результатами фізико-хімічних досліджень відібраних проб проаналізовано макро- і мікрокомпонентний склад поверхневих вод частини території полігону 3 захоронення ТПВ № 5, яка розглядається, а також 
водойми за його межами. Виявлено, що досліджені води належать до сульфатно-кальцієвого типу. Їхня мінералізація змінюється від 865 до 1220 мг/дм ${ }^{3}$. Середній вміст у них $\mathrm{Cl}^{-}$становить 22 мг/дм ${ }^{3}, \mathrm{HCO}_{3}{ }^{-}-8,2 \mathrm{мг/дм}{ }^{3}$, $\mathrm{SO}_{4}{ }^{2-}-283$ мг/дм ${ }^{3} ;$ жорсткість вод - 12,2 мг-екв./дм³.

Середній вміст мікроелементів у досліджених водах складає, мг/дм ${ }^{3}$ : $\mathrm{F}-0,35, \mathrm{Cr}-0,005, \mathrm{Ni}-0,004, \mathrm{Cu}-0,004, \mathrm{Fe}_{\text {заг. }}-0,72, \mathrm{~Pb}-0,0009$. Вміст цих мікроелементів не перевищує гранично допустимі концентрації (ГДК), однак, він вище фонових значень [17].

3 викладеного можна зробити висновок, що обладнання із системою переробки (очищення) токсичного фільтрату, яке працює на полігоні, функціонує задовільно протягом періоду, що безпосередньо передував нашим дослідженням. Очевидно рідина, яка залишалася після очищення фільтрату i розпилення іiі по площі полігону, за відсутності рясних атмосферних опадів лише в незначній кількості розтікалася по окрузі й до поверхневих вод довкілля майже не потрапляла.

Натомість хімічний склад донних відкладів, відібраних у районі площадки спостережень № 5 зі штучного ставка у нижній частині балки, що облямовує полігон поховання ТПВ з заходу і північного-заходу, змінюється з глибиною. При збільшенні глибини спостерігається зростання вмісту органічних речовин у складі цих відкладів, що визначається поверхневим змивом з карт звалища.

Валовий вміст ВМ у донних відкладах варіює у широких межах, що залежить від техногенних факторів. Так, у районі площадки спостережень № 5 виявлено аномально високе забруднення цинком - 800 мг/кг, що в 14 разів більше ГДК [17-19]. Варіації вмісту цинку в донних відкладах змінюються в межах 60-800 мг/кг.

Тут же спостерігається підвищений вміст міді - 150 мг/кг, що в 4,5 рази вище ГДК. Варіації вмісту міді змінюються в діапазоні від 50 до 150 мг/кг.

Середній вміст свинцю в донних відкладах площадки № 5 також перевищує ГДК і становить 72 мг/кг. Концентрація свинцю варіює від 60 до 180 мг/кг.

Таким чином, відповідно до критеріїв забруднення [20] донні відклади району полігону № 5 за концентраціями забруднюючих речовин характеризуються небезпечним рівнем забруднення. Не викликає сумніву, що накопичення в них зазначених полютантів стало наслідком їх виносу з тіл власне карт «А» та «Б» внаслідок технологічних порушень, вочевидь численних, протягом тривалої діяльності полігону захоронення ТПВ поблизу с. Підгірці.

Забруднення трунтових вод макро- і мікроелементами і зміна їх фізикохімічних показників підтверджується наявними даними про їхній хімічний склад зі свердловин полігону № 5. Результати досліджень представлені в таблиці 2.

Таблиця 2 - Порівняння середнього хімічного складу грунтових вод зі свердловин полігону № 5 з нормативами (мг/л)

\begin{tabular}{|l|c|c|c|c|c|c|c|c|c|c|c|c|}
\hline & $\mathrm{pH}$ & $\begin{array}{c}\text { Сухий } \\
\text { залишок }\end{array}$ & $\mathrm{Ca}^{2+}$ & $\mathrm{Mg}^{2+}$ & Хлориди & Сульфати & $\begin{array}{c}\text { Завислі } \\
\text { речовини }\end{array}$ & $\mathrm{Fe}_{\text {заг. }}$ & $\mathrm{Cu}^{2+}$ & $\mathrm{Zn}^{2+}$ & $\mathrm{Cr}^{3+}$ & $\mathrm{Ni}^{2+}$ \\
\hline $\begin{array}{l}\text { Середні } \\
\text { дані по } \\
\text { свердло- } \\
\text { винах }\end{array}$ & 7,8 & 292,0 & 2,8 & 2,1 & 44,2 & 9,6 & 120,3 & 5,2 & 0,3 & 0,25 & 0,35 & 0,21 \\
\hline ГДК & $\begin{array}{c}6,5- \\
8,5\end{array}$ & 1000,0 & 3,5 & 20,0 & 350,0 & 500,0 & 0,75 & 0,3 & 1,0 & 1,0 & 0,5 & 0,1 \\
\hline
\end{tabular}


Отже, за даними обстежень спостерігається значне перевищення у пробах грунтових вод, відібраних зі свердловин у районі полігону, ГДК по залізу і нікелю. Розрахунки показали, що у порівнянні 3 нормативними [21] загальносанітарні показники ступеня забруднення грунтових вод території досліджень належать до категорії середнього і високого ступеня забруднення. Це може свідчити про таке. По-перше, або мають місце ненадійність і прориви захисних плівок (протифільтраційних екранів) у тілі власне карт полігону та субвертикальні проникнення (витоки) фільтрату з трьох наявних на ньому величезних фільтратних озер (або ставків-фільтратонакопичувачів) до довколишніх грунтових (підземних) вод. Або ж, по-друге, забруднення грунтових вод може бути спричинене іншими факторами імовірно антропогенного походження. Це питання потребує більш ретельного дослідження у подальшому.

Таким чином, використання грунтових вод для господарсько-побутових потреб населення прилеглих до полігону № 5 сіл повинно бути дуже обмеженим, тому що це загрожує його здоров’ю. Разом з тим відомо [22], що водопостачання мешканців с. Підгірці здійснюється за допомогою двох артезіанських свердловин з бучацького водоносного горизонту, приналежного до бучацького регіоярусу еоцену палеогенової системи (Р 2 bс̌). Отож вважаємо, що вкрай необхідно здійснювати геохімічний і бактеріологічний аналіз цієї води у моніторинговому режимі.

Рослинність також зазнає негативного екологічного впливу від діяльності полігону № 5 . Зокрема, відмічається зміна біогеохімічних показників досліджених зразків трав'янистої рослинності, що зростає на полігоні. Так, до елементів значного накопичення в рослинності належать мідь, хром, нікель 3 КБП понад 2,0.

\section{Висновки та перспективи подальших робіт}

У результаті комплексних еколого-геохімічних досліджень компонентів ландшафту в районі північно-західної частини полігону № 5 з поховання ТПВ, що розташований у межах вододільного плато поблизу с. Підгірці Київської області, встановлено екологічно негативний його вплив на довкілля, насамперед на грунтові відклади. Зокрема, у трунтах зафіксовано зменшення вмісту поглинених катіонів $\mathrm{i}$ вмісту $\mathrm{C}_{\text {орг. }}$. Натомість ці техногенні грунти характеризуються значним накопиченням ВМ. Порівняно 3 умовно чистими (фоновими) грунтами вміст $\mathrm{Cu}$ у досліджених грунтах району полігону у 8 разів більше, $\mathrm{Zn}$ - у 12 разів, $\mathrm{Ni}$ - у 3, $\mathrm{Cr}$ - у 2, $\mathrm{Pb}$ - в 17 разів. Унаслідок забруднення ВM у грунтах збільшується кількість рухомих форм (водорозчинна та іонообмінна): $\mathrm{Zn}$ - в 4 рази, $\mathrm{Ni}$ - у 5 разів, $\mathrm{Cu}-$ у 6 разів, $\mathrm{Pb}$ - у 8 разів.

Валовий вміст ВМ у донних відкладах району полігону № 5 варіює у широких межах, що залежить від техногенних факторів. Так, виявлене аномально високе забруднення цинком - 800 мг/кг (у 14 разів більше ГДК), підвищений вміст міді - 150 мг/кг (у 4,5 рази вище ГДК). Середній вміст свинцю в них також перевищує ГДК і становить 72 мг/кг. За цими концентраціями донні відклади належать до небезпечного рівня забруднення.

За результатами фізико-хімічних досліджень мікрокомпонентного складу відібраних проб поверхневих вод виявлено, що вміст в них мікроелементів

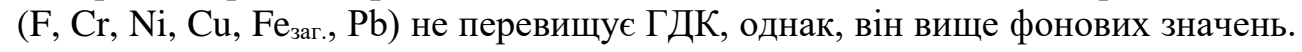


Разом з тим порівняльний аналіз середнього хімічного складу проб трунтових вод зі свердловин району полігону з нормативними показниками засвідчив, що загальносанітарні показники ступеня забруднення перших з них належать до категорії середнього i високого ступеня забруднення. Зокрема, у них відмічається значне перевищення ГДК по $\mathrm{Fe} \mathrm{i} \mathrm{Ni.} \mathrm{Отже,} \mathrm{використання}$ грунтових вод довкола території полігону № 5 для господарсько-побутових потреб населення повинно бути дуже обмеженим.

Для подальшого комплексного вивчення та об'єктивної оцінки екологогеохімічного стану розглянутих об'єктів довкілля необхідно поповнити довідкові відомості про особливості полігону № 5, провести моніторингові дослідження по регулярній мережі наземного опробування (літо-, гідро-, біогеохімічного) та за даними дистанційної зйомки. Так, для більш повного охоплення за площею території робіт потрібно підібрати й отримати зроблені субсинхронно 3 наземними дослідженнями інформативні (просторове, спектральне розрізнення) матеріали багатозональних космічних знімань, виконати гіперспектральну зйомку з борту безпілотного літального апарата по достатній кількості профілів і точок спостережень.

\section{СПИСОК ЛІТРАТУРИ}

1. Горох Н.П. Экологическая оценка вредных веществ при комплексной утилизации муниципальных отходов / Н.П. Горох // Коммунальное хозяйство городов: Науч.-техн. сб. - Харьков, 2005. - № 63. - С. 172-181.

2. Буц Ю.В. До питання екологічної небезпеки полігонів твердих побутових відходів для компонентів геосистем (на прикладі досліджень щодо концентрацій важких металів у складових геосистем) / Ю.В. Буц, А.Н. Некос // Проблеми безперервної географічної освіти і картографії: Зб. наук. пр. - Харків, 2012. - Вип. 16. - С. 22-25.

3. Baum R.L. Introduction: Hazard Mapping/ R.L Baum, T. Miyagi, S. Lee, O.M. Trofymchuk // Landslide Science for a Safer Geoenvironment. Vol. 2: Methods of Landslide Studies. Eds. Sassa K., Canuti P., Yin Y. - Cham: Springer, 2014. - P. 395-396. DOI: https://doi.org/10.1007/978-3-319-05050-8_61.

4. Самойлік М.С. Екологічні аспекти впливу полігонів твердих побутових відходів на навколишнє середовище. Фільтрат / М.С. Самойлік, А.В. Молчанова // Вісник Полтавської державної аграрної академії. - 2017. - № 1-2. - С. 88-91.

5. Azimov O.T. (2018) Reconnaissance integrated geoecological study of the disposal region for municipal solid waste with the aim of environmental assessment / O.T. Azimov, V.G. Bakhmutov, Yu.Yu. Voytyuk, Ye.M. Dorofey, S.P. Karmazynenko, I.V. Kuraeva // 12th International Conference on Monitoring of Geological Processes and Ecological Condition of the Environment (13-16 November 2018, Kyiv, Ukraine), Extended Abstracts, doi: 10.3997/2214-4609.201803142 (available at: http://www.earthdoc.org/publication/ publicationdetails/?publication=95152).

6. Азімов О.Т. Моніторинг територій полігонів твердих побутових відходів 3 використанням дистанційних технологій / О.Т. Азімов, О.В. Томченко, С.П. Кармазиненко, І.В. Кураєва, Ю.Ю. Войтюк // Формування програм щодо поводження з відходами для об'єднаних територіальних громад: проблемні питання та кращі практики: Зб. матеріалів Нац. форуму «Поводження 3 відходами в Україні: законодавство, економіка, технології» (Київ, 22-23 листоп. 2018 р.). - К.: Центр еколог. освіти та інформації, 2018. - С. 84-87.

7. Азімов О.Т. Еколого-геохімічна оцінка об'єктів довкілля територій поховання твердих побутових відходів / О.Т. Азімов, І.В. Кураєва, Ю.Ю. Войтюк, А.І. Самчук, С.П. Кармазиненко, В.Г. Бахмутов // Пошукова та екологічна геохімія. - 2018. № 1 (19). - C. 22-26. 
8. Азимов А.Т. Анализ результатов комплексных геохимических исследований образцов компонентов ландшафта из зоны влияния мест захоронения твердых бытовых отходов / А.Т. Азимов, С.П. Кармазиненко, И.В. Кураева, Ю.Ю. Войтюк // Сб. науч. тр. по материалам Междунар. науч. экол. конф. «Отходы, причины их образования и перспективы использования» (г. Краснодар, 26-27 марта 2019 г.) / Сост. Л.С. Новопольцева; под ред. И.С. Белюченко. - Краснодар: КубГАУ, 2019. - С. 198200. - Режим доступу: http://www.ecokavkaz.ru/media/docs/conf/conf2019.pdf.

9. Ландшафтно-геохимическая карта Украины. Масштаб 1:1500000/ Сост. В.И. Почтаренко, В.П. Иванчиков / Гл. ред. А.И. Зарицкий. - Киев: Гос. комитет Украины по геологии и использованию недр, Гос. геол. предприятие «Геопрогноз», 1994.

10. https://www.google.com/maps.

11. Охрана природы. Почвы. Методы отбора и подготовки проб для химического, бактериологического, гельминтологического анализа: ГОСТ 17.4.4.02-84. [Действующий от 1986-01-01]. - М.: Стандартинформ, 2008. - 8 с.

12. Вода. Общие требования к отбору проб: Государственный стандарт РФ ГОСТ Р 51592-2000 (принят и введен в действие постановлением Госстандарта РФ от 21 апреля 2000 г. № 117-ст.). - [Дата введения 1 июля 2001 г.]. - М.: Изд-во Госстандарт, 2000. - 12 с.

13. Охрана природы. Гидросфера. Общие требования к отбору проб донных отложений водных объектов для анализа на загрязненность: ГОСТ 17.1.5.01-80. - [Действующий с 01.01.1982]. - М.: Госстандарт СССР, 1981. - 7 с.

14. Самчук А.И. Физико-химические условия образования мобильных форм токсичных металлов в почвах / А.И. Самчук, Г.Н. Бондаренко, В.В. Долин, Ю.Я. Сущик, И.Ф. Шраменко, Б.Ф. Мицкевич, О.С. Егоров // Минералогический журнал. - 1998. - Том 20, № 2. - С. 48-59.

15. Авессаломова И.А. Геохимические показатели при изучении ландшафтов. Учебнометодическое пособие. - М.: Изд-во МГУ, 1987. - 108 с.

16. Жовинский Э.Я., Кураева И.В. Геохимия тяжелых металлов в почвах Украины. Киев: Наук. думка, 2002. - 213 с.

17. Никитин Д.П., Новиков Ю.В., Рощин А.В., Жилов Ю.Д., Марченко Д.Г., Ясинский А.А. Справочник помощника санитарного врача и помощника эпидемиолога / Под ред. Д.П. Никитина, А.И. Заиченко. - [2-е изд., перераб. и доп.]. М.: Медицина, 1990. -512 с.

18. Методические рекомендации по гигиеническому обоснованию ПДК химических веществ в почве. - [2-е изд.]. - М.: Минздрав СССР, 1982. -59 с.

19. Охрана природы. Почвы. Классификация химических веществ для контроля загрязнения: ГОСТ 17.4.1.02-83. - [Дата введения 01.01.1985]. - М.: Стандартинформ, 2008. -4 c.

20. Андросова Н.К. Геолого-экологические исследования и картографирование (Геоэкологическое картирование): Учебное пособие. - М.: Из-во Рос. ун-та дружбы народов, 2000. - 98 с.

21. Санитарные правила и нормы охраны поверхностных вод от загрязнения: СанПиН № 4630-88. - [Вводится вновь с 1.01.1989 г.]. - М.: Минздрав СССР, 1988. - 59 с.

22. Олійник В., Чубенко О., Грановський О., Гуржий Д., Заброда А., Чуприна М., Іванова І., Кудлай О., Чубенко О., Ладановський В. Внесення змін до генерального плану с. Підгірці Обухівського району Київської області. Договір № 29/08-ГП від 03.10.2016 p. / ТОВ «ПРОЕКТГЕНПЛАН». - Арх. № ГП-29/08-009. - К., 2018. - Том I. $102 \mathrm{c}$.

Стаття надійшла до редакиії 21.03.2019 і прийнята до друку після рецензування 23.04.2019 


\section{REFERENCES (TRANSLATED AND TRANSLITERATED)}

1. Horokh, N.P. (2005) Ekolohycheskaia otsenka vrednykh veshchestv pry kompleksnoi utylyzatsyy minitsypalnykh otkhodov. Kommunalnoe khoziaistvo horodov - Municipal economy of cities: Scientific \& technical collection (Ukraine), Kharkov, No 63, 172-181 (in Russian).

2. Buts, Yu., \& Nekos, A. (2012) On environmental hazards for the geosystems' components on testing grounds for municipal solid waste (research on heavy metal concentrations in components of geosystems). Problemy bezperervnoi heohrafichnoi osvity $i$ kartografii - Problems of Continuous Geographic Education and Cartography: Scientific journal (Ukraine), Kharkiv: V.N. Karazin Kharkiv National University, Issue 16, 22-25 (in Ukrainian).

3. Baum, R.L, Miyagi, T., Lee, S., \& Trofymchuk, O.M. (2014) Introduction: Hazard Mapping. In: Sassa, K., Canuti, P., \& Yin, Y. (Eds.) Landslide Science for a Safer Geoenvironment. Vol. 2: Methods of Landslide Studies. Cham: Springer, 395-396, doi: https://doi.org/10.1007/978-3-319-05050-8_61.

4. Samoilyk, M.S., \& Molchanova, A.V. (2017) Ecological aspects of influence of solid domestic wastes on the environment. Filtrate. Visnyk Poltavskoi derzhavnoi ahrarnoi akademii - Bulletin of Poltava State Agrarian Academy (Ukraine), No 1-2, 88-91 (in Ukrainian).

5. Azimov, O.T., Bakhmutov, V.G., Voytyuk, Yu.Yu., Dorofey, Ye.M., Karmazynenko, S.P., \& Kuraeva, I.V. (2018) Reconnaissance integrated geoecological study of the disposal region for municipal solid waste with the aim of environmental assessment. 12th International Conference on Monitoring of Geological Processes and Ecological Condition of the Environment (13-16 November 2018, Kyiv, Ukraine), Extended Abstracts, doi: 10.3997/2214-4609.201803142 (available at: http://www.earthdoc.org/publication/ publicationdetails/?publication=95152).

6. Azimov, O.T., Tomchenko, O.V., Karmazynenko, S.P., Kuraeva, I.V., \& Voytyuk, Yu.Yu. (2018) Monitoring the municipal solid waste landfill areas using the remote sensing technologies. Program development on the waste management for the united territorial communities: key problematic issues and the best practices: Proceedings of National Forum "Waste management in Ukraine: legislation, economics, technologies" (Kyiv, 22-23 November 2018). Kyiv: Centre for the ecological education and information, 84-87 (in Ukrainian).

7. Azimov, O.T., Kuraeva, I.V., Voytyuk, Yu.Yu., Samchyk, A.I., Karmazynenko, S.P., \& Bakhmutov, V.G. (2018) Ecological-geochemical assessment of the territories for the municipal solid waste disposal. Poshukova ta ekolohichna geokhimiia - Exploration and Environmental Geochemistry (Ukraine), No 1(19), 22-26 (in Ukrainian with English summary).

8. Azimov, O.T., Karmazynenko, S.P., Kuraeva, I.V., \& Voytyuk, Yu.Yu. (2019) Analysis of the results of the complex geochemical investigations of samples for the landscape components within the affected zone of municipal solid waste disposal areas. In: Proceedings of International Scientific Ecological Conference "Waste, the reasons of their formation and prospects of utilization" (Krasnodar city, 26-27 March 2019) / Compiler Novopoltseva L.S.; Ed. Beliuchenko I.S. Krasnodar: Kuban State Agrarian University, 198-200 (available at: http://www.ecokavkaz.ru/media/docs/conf/conf2019.pdf) (in Russian).

9. Pochtarenko, V.I., \& Ivanchikov, V.P. (1994) Landscape geochemical map of Ukraine. Scale of 1:1 500000 / Ch. Ed. Zaritskiy, A.I. Kyiv: State Committee of Ukraine for Geology and the Use of Subsurface Resources, State Geological Enterprise «Geoprognoz» (in Russian).

10. https://www.google.com/maps.

11. Environmental protection. Soils. Methods of sampling and preparing of samples for the chemical, bacteriological, and helminthological analyses: GOST 17.4.4.02-84 (2008). [Acting after 1986-01-01]. Moscow: Standardinform (in Russian). 
12. Water. General requirements to collection of samples. State Standard, Russian Federation GOST R 51592-2000 (2000) (adopted and brought into action by the decision of Gosstandart of Russia after 21 April, 2000, N 117 particle). [Date of Entry - 1 July, 2001]. Moscow: Gosstandart Press (in Russian).

13. Nature protection. Hydrosphere. General requirements for sampling of bottom sediments of water objects for their pollution analysis: GOST 17.1.5.01-80 (1980). [Acting after 01.01.1982]. Moscow: Gosstandart of USSR (in Russian).

14. Samchuk, A.I., Bondarenko, G.N., Dolin, V.V., Sushchik, Yu.Ya., Shramenko, I.F., Mitskevich, B.F., \& Egorov, O.S. (1998) Physical and chemical conditions promoting formation of mobile forms of toxic metals in soils. Mineralogicheskiy zhurnal Mineralogical journal (Ukraine), Vol. 20, No 2, 48-59 (in Russian with English summary). 15. Avessalomova, I.A. (1987) Geochemical indices in landscape investigation. Educational learning guide. Moscow: Moscow State University Press (in Russian).

16.Zhovynskyi, E.Ya., \& Kuraeva, I.V. (2002) Geochemistry of heavy metals in the soils of Ukraine. Kyiv: Naukova dumka (in Russian).

17. Nikitin, D.P., Novikov, Yu.V., Roschin, A.V., Zhilov, Yu.D., Marchenko, D.G., \& Yasinskiy, A.A. (1990) Manual of health assistant and epidemiologist assistant / Eds. Nikitin, D.P., \& Zaichenko, A.I. 2nd Ed., revised and enlarged. Moscow: Meditsina (in Russian).

18. Recommended practice on hygienic substantiation of the TLV for the chemical compounds in soils (1982). 2nd Ed. Moscow: MOH of USSR (in Russian).

19. Nature protection. Soils. Classification of chemicals for pollution control: GOST 17.4.1.02-83 (2008). [Date of Entry - 01.01.1985]. Moscow: Standardinform (in Russian).

20. Androsova, N.K. (2000) Geological-ecological studies and mapping (Geoecological mapping): Educational guidance. Moscow: Russian Peoples' Friendship University Press (in Russian).

21. Sanitary Regulations for Protection of Surface Water from Pollution: SANPIN 4630-88 (1988). [Adopted again after 1.01.1989]. Moscow: MOH of USSR (in Russian).

22. Oliinyk, V., Chubenko, O., Hranovsky, O., Hurzhyi, D., Zabroda, A., Chupryna, M., Ivanova, I., Kudlai, O., \& Ladanovsky, V. (2018) Making changes to the General Plan for the Pidhirtsi village, Obukhiv Raion, Kyiv's Oblast. Agreement N 29/08-GP on 03.10.2016 I Archives. N GP-29/08-009. Vol. I. Kyiv: Association «Proektgenplan» (in Ukrainian).

The article was received 21.03.2019 and was accepted after revision 23.04.2019

\section{Азімов Олександр Тельманович}

доктор геологічних наук, старший науковий співробітник, провідний науковий співробітник Наукового центру аерокосмічних досліджень Землі Інституту геологічних наук НАН України

Адреса робоча: 01054 Україна, м. Київ, вул. О. Гончара, 55-б

e-mail:azimov@casre.kiev.ua

ORCID ID 0000-0002-5210-3920

\section{Трофимчук Олександр Миколайович}

доктор технічних наук, професор, член-кореспондент НАН України, директор Інституту телекомунікацій і глобального інформаційного простору НАН України

Адреса робоча: 03186 Україна, м. Київ, Чоколівський бульвар, 13

e-mail: itelua@kv.ukrtel.net

ORCID ID 0000-0003-3782-4209 


\section{Курасва Ірина Володимирівна}

доктор геологічних наук, професор, завідувач відділу геохімії техногенних металів та аналітичної хімії Інституту геохімії, мінералогії та рудоутворення імені М.П. Семененка НАН України

Адреса робоча: 03680 Україна, м. Київ, проспект Академіка Палладіна, 34

e-mail: ki4412674@gmail.com

ORCID ID 0000-0003-3113-7782

\section{Кармазиненко Сергій Петрович}

кандидат географічних наук, старший науковий співробітник Інституту географії НАН України

Адреса робоча: 01030 Україна, м. Київ, вул. Володимирська, 44

e-mail: karmazinenko78@gmail.com

ORCID ID 0000-0001-8268-7851 